\title{
The transformation of professors' careers: standardization, hybridization, and acceleration?
}

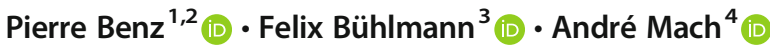 \\ Published online: 9 July 2020 \\ (C) The Author(s) 2020, corrected publication 2020
}

\begin{abstract}
Over the recent decades, the turn to managerial governance has thoroughly transformed the European university systems and, by extension, the careers of university professors. Scholars postulated that professors' careers have undergone an increasing formalization, that disciplinary careers have been hybridized, and that new modes of selection and recruitment (through assistant professorship) have been introduced. This article, based on a case study of the EPFL Lausanne, one of the leading European technical universities, aims to understand these changes by conducting a sequence analytical study of the actual trajectories of professors. By studying the careers of 351 professors who were nominated between 1969 and 2010 at the EPFL, we first develop a typology of professors' careers. We distinguish between "direct careers," "seniority careers," "conversion careers," and "parallel careers." We then examine, based on a series of binomial logistic regression models, how career types vary according to the nomination cohort, the discipline, and the recruitment mode. Our results show that slower "seniority careers" within academia have become more important in recent cohorts, that disciplinary logics still shape professors' careers, and that new recruitment mechanisms, such as assistant professorship, do not necessarily lead to accelerated careers. This article contributes to the literature by showing that beyond the analysis of the institutional setting of academic careers, it is also important to study their actual progression.
\end{abstract}

Keywords Careers · Entrepreneurial university $\cdot$ Academic elites $\cdot$ Sequence analysis $\cdot$ Assistant professorship · Engineering sciences

Pierre Benz

Pierre.Benz@hetsl.ch

Felix Bühlmann

Felix.Buhlmann@unil.ch

André Mach

Andre.Mach@unil.ch

Extended author information available on the last page of the article 


\section{Introduction}

The turn to managerial governance has thoroughly transformed many university systems in the last two decades (Musselin 2005). An example of this trend is the emergence of "entrepreneurial universities," which are defined as "actively seeking to innovate in how [they go] about their business, through substantial shift in their organization" (Clark 1998: 4). Entrepreneurial universities are concerned with efforts to "stimulate their academic heartland" and promote a more rigorous academic culture (Clark 1998). This endeavor has led to new forms of training, recruitment, and promotions of university professors. Academic careers have supposedly become more formalized and standardized, resulting in a reconfiguration of the social and power relationships within the academic field (Fumasoli and Goastellec 2015; Bourdieu 1984). Others argue that the simultaneous reinforcement of outreach and academicization would have "hybridized" the division between "applied" and "fundamental" research disciplines (Enders and de Weert 2004). Furthermore, the increasing internationalization and the policy exchange between national systems would have led to a spread of accelerated forms of selection and recruitment of professors, such as through the introduction of assistant professorships (Kreckel and Zimmermann 2014; Goastellec and Benninghoff 2011). This article aims to investigate these propositions through an analysis of the real progression of professors' careers.

Empirically, we study the transformations of the careers of the professors at the Swiss Federal Institute of Technology Lausanne (EPFL), an institution that has programmatically adopted the framework of the entrepreneurial university and accelerated its transformation from a local engineering school to one of the highest-ranked European universities (Aebischer and Ricci 2006). Three research questions structure our study: First, have professors' careers become more standardized in the recent period? Second, what about the career differences in pure and applied disciplines? Third, how has the introduction of positions, such as assistant professorships, transformed careers in recent years? On the basis of a sequence analysis of the careers of 351 professors who were nominated between 1969 and 2010 at EPFL, we first identify four typical career types. In a second step, we examine what role cohorts of nomination, disciplines, and the introduction of assistant professorships (with a stress on international experience) play in the different career types. Our article contributes to the literature by focusing on the actual sequential deployment of careers. Our results show how professors' careers have changed as a result of recent organizational changes, and encourage further research focusing on actual career pathways of professors.

The article is organized as follows: in the "Theory" section, we discuss universities' recent institutional transformations and their potential repercussions on academic careers. We then present our case study, the EPFL, and formulate three research questions, followed by a presentation of the data and method. In the "Results" section, we present four career types (direct, seniority, parallel, and conversion) and, using binomial regression, show how they relate to cohort, discipline, and assistant professorship. We round off the article by a conclusion that revisits our research questions and relates our findings to the wider context of the transformation of the academic landscape.

\section{Theory}

\section{The academic space and its recent transformation}

According to Bourdieu (1984), a social space (or a field) attributes positions to persons according to three fundamental dimensions: the volume of different forms of capital (generally 
economic capital, cultural capital, or social capital), the structural composition of this capital (the relative shares of different forms of capital), and the social trajectory. Therefore, a field is a relatively autonomous space that is characterized by the relationship between positions which are endowed with different volumes and compositions of capital. The capital volume and blend are the results of an accumulation and conversion of capital across biographical trajectories. When Bourdieu applied his concept of the field to the academic world (Bourdieu 1976, 1990), he highlighted the importance of two types of capital: scientific capital and institutional capital. The first corresponds to the scientific reputation an academic enjoys among his peers and can be measured by indicators such as prestigious publications, scientific prizes, or renowned chair positions. The second type of capital corresponds to influential executive positions within the university administration. Professors at the "scientific pole" possess a large amount of scientific capital, are renowned among their peers, and pursue an exclusively academic career. By contrast, their colleagues at the "worldly pole" sit in administrative, political, and economic committees, and consequently own only little scientific capital (Bourdieu 1990).

Bourdieu's study of the academic field raises the issue of the links between types of capitals and the changing governance of academic institutions. Indeed, the latter plays a significant role in determining the most valued types of capitals: scientific, institutional, but also what certain have dubbed applied forms of capital (Braun 2001). Consequently, the profound re-organization of the EPFL into an entrepreneurial university has likely also challenged the relative valuation of these capitals. Although it does not provide a direct answer to this issue, Clark's book on entrepreneurial universities (1998) presents an analysis of universities that tried to challenge Bourdieu's traditional university space. ${ }^{1}$ Clark (1998) brings five shared elements to the fore: entrepreneurial universities would first strengthen their steering core and would "need to become quicker, more flexible, and especially more focused in reactions to expanding and changing demands" (Clark 1998: 5). Second, they were supposed to reinforce interdisciplinary research centers that could reach outward and strengthen the collaborations with non-academic partners. These partners from the business or the administrative world could, third, also contribute to a "diversity of the funding base." Then, an entrepreneurial university should also "strengthen its academic heartland" by blending "academic values" with a "managerial point of view" in order to develop "polyvalent knowledge" (Etzkowitz and Viale 2010) and, finally, integrate into an entrepreneurial culture. Another challenge to Bourdieu's depiction of the traditional (French) universities of the 1960s was the increasing internationalization of university personnel (Goastellec and Benninghoff 2011; Vaara and Faÿ 2012), the growing international circulation of university policies (Paradeise and Crow 2009), and the links between the structure of capitals and the changing models of academic institutions' governance (Braun 2001).

\section{A resource-based career analysis}

We propose to analyze the forms of capital that are concretely valued through professors' careers, defined as a succession of occupational positions, events, or circumstances during the life course of an individual (Hughes 1937; Becker 1963; Abbott and Hrycak 1990; Bühlmann 2008). By moving through these occupational positions, professors are able to acquire, accumulate, and convert resources that they might need to obtain further positions in their careers (Savage et al. 2005;

\footnotetext{
${ }^{1}$ While it proposes more of an organizational approach, the implementation of the entrepreneurial university may vary according to national higher education systems (Sam and Van Der Sijde 2014; Foss and Gibson 2015).
} 
Rossier 2020). We argue that, as a consequence of organizational changes, the forms of capital professors acquire through their career must be adapted in comparison with Bourdieu's assertions: while traditional academic careers are mostly relying on scientific capital, the introduction of new organizational models (i.e., new public management and entrepreneurial university) gives more weight to applied forms of capitals ${ }^{2}$ (Braun 2001).

Especially in technical universities, practical capital acquired through extra-academic professional (and local) experiences (for example, in engineering office) is highly likely to by convertible in tenured positions. In the context of entrepreneurial universities, these practical experiences can yet take a different flavor: knowledge transfers, experiences in start-ups, or positions as experts and consultants on corporate boards become increasingly valued. International experiences-longer stays abroad and regular exchanges co-authorship with colleagues from other countries - have also increasingly been valued in the academic field in recent decades and can be considered a new form of capital (that was hardly discussed by Bourdieu). By extending the Bourdieusian framework (Vaara and Faÿ 2012), we call these resources “international capital' (Bühlmann et al. 2013). They endow professors with prestige and can be transformed into academic positions in one's home country (Goastellec and Pekari 2013). The perceived superiority given to these experiences might also challenge practical and local scientific capitals, and might even work as a career accelerator.

Through a career within the academic field, professors accumulate capital and occupy, depending on this accumulation process, positions that are endowed with specific forms of capital. While scientific capital is the very essence of the scientific activity, other resources can be transferred from one field to another through a process of conversion: individuals can get a position through the importation of extra-field resources. For example, the previously mentioned practical resources accumulated through a career in the corporate world can be considered a relevant expertise by the actors of the academic field and be converted into academic positions. The necessary conditions for the accumulation or conversion of resources may depend on governance models, disciplinary specificities, and national contexts. Moreover, the access to the positions during the career can follow different temporal rhythms: from a quick acquisition of capital during the first steps of the career, allowing a conversion directly to professorship to a progressive "capitalization" process, leading to a gradual accumulation of capital.

\section{The transformations of academic careers}

Three aspects focus on the recent debate about professors' careers: their increasing formalization and standardization, the hybridization of disciplinary career models, and the introduction of mechanisms of selection and recruitment.

The first aspect of the transformations of academic careers concerns their increasing formalization and standardization in the last 20 years (Musselin 2005). In most Western academic systems, formal criteria for the selection of future professors have been enforced, and new positions and measures have been promoted to optimize the selection and recruitment of professors (Goastellec and Benninghoff 2011). Consequently, professors' careers are potentially slowed down: a doctorate becomes increasingly compulsory and the post-doctoral period takes increasingly longer, albeit to a certain extent depending on national peculiarities (Stephan and Ma 2005). ${ }^{3}$ Generally speaking,

\footnotetext{
${ }^{2}$ In what follows, we are going to call these forms practical capital.

${ }^{3}$ The German and the Swiss systems have been characterized by a long period spent in relatively unstable positions before the tenure, but not necessarily in applied sciences universities (Enders 2001). Moreover, no habilitation is required in certain regions in Switzerland (Goastellec and Benninghoff 2011), which shortens the period, comparable to the French case (Musselin 2005).
} 
potential candidates might have to go abroad, apply for post-doctoral programs, and collect experiences at different institutions and in various positions, which are sometimes related to a certain "precarization" of employment and appointment, eventually to a temporal extension of the pre-tenure phase (Fumasoli and Goastellec 2015).

The second aspect involves scientific disciplines as an important part of the framing of professors' careers (Kaulisch and Enders 2005). A key distinction runs between "pure" and "applied" sciences. "Pure" or "basic research" can be defined as "a method of investigating nature by the experimental method in an attempt to satisfy the need to know," and "applied science" is recognized as "the use of pure science for some practical human purpose" (Feibleman 1961). As the first represent the "autonomous" pole of the scientific field (Bourdieu 1976), we would expect the process of the accumulation of scientific capital within the academic field to characterize careers of "pure" scientists. By contrast, the process of conversion of practical resources could function as a typical trajectory for professors of "applied sciences." The concept of the entrepreneurial university suggests that this distinction between pure and applied science has undergone a hybridization through transdisciplinary projects, socially accountable outputs, and polyvalent knowledge (Gibbons et al. 1994; Clark 1998; Etzkowitz and Viale 2010). We can expect that careers in pure discipline also now integrate certain forms of practical capital (corporate experiences, spin-offs, etc.) and professors in applied science become more academic (hold a doctorate and spend more time in postdoctoral training).

The third aspect concerns the introduction of new recruitment models, especially assistant professorships. For professors' careers, the phase of pre-tenure is particularly delicate. We can distinguish between gradual systems with possible mobility between a series of hierarchically ordered (tenured) positions (such as in the USA, the UK, and, to a certain extent, France) and "cesura systems" with a large and binary difference between tenured professors and non-tenured academic personnel (Kreckel and Zimmermann 2014). Particularly in the latter, the recruitment procedures have been criticized and new elements of a more gradual system have been introduced. As a first career step, assistant professor positions were offered to young academics, in the hope that they contribute to a more efficient and smooth selection of tenured professors. ${ }^{4}$ The actual impact of these reforms, however, is contested (Musselin 2005). According to a first thesis, assistant professorship allows universities to identify young scientific talents early and to retain them by offering attracting conditions and responsibilities that resemble those of tenured professors. According to a second thesis, assistant professorships are periods of often precarious scientific socialization and can also lead to a career slow-down. Whether an assistant professorship functions as a career accelerator or as a career slowing-down, the socialization phase depends on the concrete modalities (Schuster and Finkelstein 2006: 163).

\section{Context and research questions}

\section{Case study}

The case of the EPFL Lausanne is particularly relevant to study the transformations of professors' careers. As one of the two Swiss federal institutes of technology, it has historically

\footnotetext{
${ }^{4}$ See the introduction of junior professors in Germany (2002) or "Förderprofessuren" of the Swiss National Science Foundation (Fumasoli and Goastellec 2015).
} 
developed close links with the private industry and serves as an interface between the academic sphere and the corporate world (Cosandey 1999; Pont 2010). It combines teaching and research that is particularly adapted to the needs of the private sector together with more basic research. Since 2000, the EPFL has rapidly turned from an engineering school into an "entrepreneurial university" (Clark 1998) and gained strong visibility at the international level. ${ }^{5}$ This rapid re-organization is a good example of the growing empowerment of universities as institutional actors, and the move of policies and practices from professional to managerial governance models (Musselin 2013; Kaulisch and Enders 2005).

Another reason why the EPFL is an interesting study case is its strong autonomy regarding academic staff recruitment, supported by a "presidential regime" which gives a great deal of organizational and strategic competences to the institution (Leresche et al. 2012). The lack of a common governance framework that characterizes the Swiss university system allows each academic institution to be a unique case of governance, while the political authorities only have limited decision power (Lepori 2007: 120). The institutional context of the Swiss academic field has changed from a local rootedness, valuing industrial experiences through extra-academic careers, to a system based on the principles of new public management and competitive instruments (Benninghoff and Braun 2010). In the late 1990s, these management principles were introduced to increase the central state's influence in the higher education sector, by formalizing new relationships between academic institutions and their regulatory authority. These macro policies have enabled the Swiss Confederation to explicitly support the organizational reforms that are introduced by the new EPFL president, appointed in 1999 (Leresche et al. 2012). Somewhat paradoxically, these reforms have thus given the EPFL greater autonomy and allowed for the implementation of an "entrepreneurial university" system.

The strategy of international development based on competitiveness and the recruitment of international scholars (Aebischer and Ricci 2006) has led to four main elements of reorganization. First, the system has been restructured from 12 departments into five "schools" and two "colleges" relying on specific disciplines. Second, a new School of Life Sciences was created in 2003, beside the disciplines that were historically represented: basic sciences (SB), civil engineering (ENAC), mechanical engineering (STI), and computer sciences (IC). This perfectly underlined the global strategy to enhance the scientific legitimacy of the institution along with the development of new relations with the corporate world. Third, the EPFL has generalized the appointments of assistant professors and introduced a tenure track system in 2001: the number of assistant professors increased from 18 in 2000 to 70 in 2016 . At that time, 63 hold a tenure track and only seven are assistant professors without a tenure track. Finally, the EPFL has also reinforced strategic partnerships with the corporate world. In 2017, the EPFL Innovation Park hosted 23 large companies and over 120 spin-offs. $^{6}$

\section{Research questions}

Based on this case study, we can now formulate three research questions:

Question 1: How has the transition to the model of the entrepreneurial university impacted professors' careers? We would expect that the phase with non-tenured positions

\footnotetext{
${ }^{5}$ It reached the top 12 of the QS World University Rankings® 2018 and the top 14 of the Shanghai Academic Ranking of World Universities in Engineering/Technology and Computer Sciences 2015.

${ }^{6}$ https://epfl-innovationpark.ch/
} 
lasts longer and that fewer professors have occupational spells outside academia.

Question 2: Do academic careers differ with respect to the distinction between fundamental natural science disciplines and applied disciplines? Have applied disciplines adapted to the career trajectories of scientific disciplines? Inversely, have practical experiences outside the university also become part of professors' careers in pure science disciplines?

Question 3: What is the impact of new recruitment models on professors' careers? Does an assistant professorship contribute to the acceleration of professors' careers? Conversely, does it rather slow down professors' careers, as suggested by the thesis of the precarious academic socialization? In addition, we examine the place of assistant professorship and ask whether this dimension matters for professors' future career.

\section{Method and data}

\section{Sample and data}

Our empirical analysis is based on a sample of 351 EPFL professors who were nominated between 1969 and 2010. This sample includes all professors who held an associate or full professorship at minimum during one of the following three benchmark years: 1980, 2000, and $2010 .^{7}$ These points in time divide the sample into three cohorts based on the year of nomination at the tenured position. The 1980 cohort $(N=113)$ is composed of the professors who were nominated between 1969 and 1980. The 2000 cohort $(N=115)$ gathers the professors who were nominated between 1981 and 2000, and the 2010 cohort includes professors who were nominated between 2001 and $2010(N=123)$. This strategy allows us to consider organizational changes by comparing cohorts.

We collected data on professors' careers from the age of 20 to the age of 50: every academic and non-academic positions occupied, the year of beginning and ending for each position, and the workplace country. The data on the professors include their date of birth, nationality, sex, institutional disciplinary affiliation, institution, department and country, year and place of education degrees, the involvement in start-ups, and the memberships in board of directors of private companies.

The three cohorts of nomination differ in terms of disciplines, nationalities, country of $\mathrm{PhD}$, and assistant professorship (Table 1). The 1980 cohort is characterized by Swiss professors $(80.5 \%)$ who obtained their $\mathrm{PhD}$ in Switzerland (43.3\%) or who have no $\mathrm{PhD}(38.9 \%)$. Professorship positions are relatively equally distributed among basic sciences, civil engineering, and mechanical engineering. The 2000 cohort shows an increase in professors with foreign nationalities (from 19.5 to $46.1 \%$ ) and an increase in PhDs obtained abroad (from 18 to $47 \%$ ). The percentage of professors with no PhD decreases to $14.8 \%$. Regarding disciplines, computer sciences are introduced, and the proportion of basic sciences and civil

\footnotetext{
${ }_{7}$ The professors for 1980 and 2000 were identified through the Annuaires des universités et hautes écoles suisses, which list all professors within Swiss universities during a given year. As such a repertory was not available for the year 2010, the professors were identified through the appointment and retirement announcements provided by the ETH board.
} 
Table 1 Descriptive sample information

\begin{tabular}{|c|c|c|c|c|}
\hline & $\begin{array}{l}1980 \text { cohort }(1969- \\
1980)\end{array}$ & $\begin{array}{l}2000 \text { cohort }(1981- \\
2000)\end{array}$ & $\begin{array}{l}2010 \text { cohort }(2001- \\
2010)\end{array}$ & $\begin{array}{l}\text { Total } \\
N\end{array}$ \\
\hline Case number & 113 & 115 & 123 & 351 \\
\hline \multicolumn{5}{|l|}{ Sex } \\
\hline Male & 113 & 111 & 112 & 336 \\
\hline Female & 0 & 4 & 11 & 15 \\
\hline \multicolumn{5}{|l|}{ Department } \\
\hline Basic Sciences (SB) & 36 & 26 & 40 & 102 \\
\hline Civil Engineering (ENAC) & 45 & 33 & 19 & 97 \\
\hline $\begin{array}{l}\text { Mechanical Engineering } \\
\text { (STI) }\end{array}$ & 32 & 41 & 19 & 92 \\
\hline Computer Science (IC) & 0 & 14 & 12 & 26 \\
\hline Life Sciences (SV) & 0 & 0 & 23 & 24 \\
\hline $\begin{array}{l}\text { Technology Management } \\
\text { (MT) }\end{array}$ & 0 & 0 & 10 & 10 \\
\hline \multicolumn{5}{|l|}{ Nationality } \\
\hline Swiss & 91 & 62 & 45 & 198 \\
\hline European & 16 & 35 & 40 & 91 \\
\hline American & 2 & 6 & 10 & 18 \\
\hline Other nationalities & 4 & 12 & 28 & 44 \\
\hline \multicolumn{5}{|l|}{ Country of $\mathrm{PhD}$} \\
\hline Switzerland & 49 & 44 & 37 & 130 \\
\hline Germany and France & 8 & 19 & 28 & 55 \\
\hline USA & 8 & 17 & 27 & 52 \\
\hline Other countries & 4 & 18 & 27 & 49 \\
\hline No $\mathrm{PhD}$ & 44 & 17 & 4 & 65 \\
\hline \multicolumn{5}{|l|}{ Place of assistant professorship } \\
\hline EPFL & 0 & 7 & 19 & 26 \\
\hline Switzerland & 3 & 5 & 8 & 16 \\
\hline Abroad & 8 & 14 & 23 & 45 \\
\hline No position & 102 & 89 & 73 & 264 \\
\hline \multicolumn{5}{|c|}{ Age of appointment at tenured position } \\
\hline EPFL (mean) & 40 & 41 & 44 & 42 \\
\hline All institutions (mean) & 38 & 39 & 40 & 39 \\
\hline
\end{tabular}

engineering decreases. Finally, only $36.6 \%$ of the professors of the 2010 cohort are Swiss and only $30.1 \%$ of this cohort obtained their $\mathrm{PhD}$ in Switzerland. At the disciplinary level, we note the introduction of the life sciences and technology management. Basic sciences grow again in importance, while civil and mechanical engineering strongly decrease. We also notice that the rate of professors who held an assistant professorship in their career is growing from less than 10 for the 1980 cohort to $40 \%$ for the 2010 cohort. This overview of the EPFL professors indicates a tendency toward scientific capital (increase in $\mathrm{PhD}$ holders and decrease in technical sciences), combined with internationalization in terms of nationalities and country of $\mathrm{PhD}$. The high proportion of $\mathrm{PhD}$ in the USA for the two last cohorts (on average $20 \%$ of all $\mathrm{PhDs}$ ) is an empirical evidence of the high symbolic value attributed to this country in particular.

\section{Research strategy}

In a first step, we identify typical career types based on a sequence analysis performed using the TraMineR package for $\mathrm{R}$ (Gabadinho et al. 2011). Sequence analysis is a longitudinal 
method that allows us to quantitatively describe life courses. It is therefore particularly relevant for the study of careers (Abbott and Hrycak 1990) and aims to describe, compare, and classify individual trajectories subdivided into successive states of career (Blanchard et al. 2014; Dlouhy and Biemann 2015). The optimal matching (OM) algorithm measures the degree of similarity between the sequences. It computes a distance matrix based on the set of specific costs of transition between the states. The optimal distance is then calculated as the minimum costs needed to transform a sequence to another. To focus our analysis on the transition (accumulation and conversion of resources) from the pre-tenure and the extra-academic states to the tenured states (associate or full professorship), we set higher substitution costs between the extra-academic states and all other states at a value of 4 . By doing so, we highlight the differences between processes of conversion and accumulation of scientific and practical capitals. Furthermore, by keeping all other substitution costs at 2, the set of the indel costs at 3 prevents an over-evaluation of the full professor state through its duration. In order to distinguish different career types, we run a hierarchical cluster analysis on the sequences.

In a second step, to explain the typical trajectories, we run a binomial logistic regression on each type of career. Instead of using a model with categorically dependent variables (Long 1997), we run four separate models; each binarydependent variable opposes the individual affiliation to a type of career (the cluster identified by sequence analysis) to not to be in the cluster. In order to compare the effect size of our variables, we used a series of control variables and calculated the average marginal effects.

\section{Variables}

The construction of the dependent variable (i.e., career types) relies on a cluster analysis on the outcome of the sequence analysis. The positions occupied by each professor from year 20 to year 50 are gathered into an "alphabet" that lists the different "states" of the career. The academic career is divided into three states related to scientific capital: pre-tenure positions, associate professorships, and full professorships (Table 2). Other states are related to other steps of the career, such as education time or extra-academic career (related to practical capital).

\section{Results}

\section{Four career types}

In this first step, we create a typological description of all of the professors' careers across all cohorts, disciplines, and statuses. We therefore analyzed all 351 careers, calculated the distance matrix, and classified the careers according to a ward-clustering procedure (Fig. 1). The silhouette analysis indicates that four clusters give the statistically most adequate number of solution.

The four distinct clusters are characterized by a specific composition, ordering, and duration of career spells: We call these careers "direct," "seniority," "conversion," and "parallel." Whereas the career types "conversion" and "parallel" combine spells in the corporate world with spells in academia, "direct" and "seniority" are almost exclusively academic career types.

Direct $(n=148,42 \%)$ : The direct type likely corresponds the closest to a collective imaginary of professors' career and also is the most widespread career type at the EPFL. It 
Table 2 Variable description

\begin{tabular}{|c|c|}
\hline States of the SA & Description and categories \\
\hline Education & From year 20 to year of highest degree ( $\mathrm{PhD}$, engineer degree, etc.). \\
\hline Pre-tenure positions & $\begin{array}{l}\text { Academic positions between the end of the education and the nomination to a } \\
\text { tenured position. Assistant professorships are included in this state. }\end{array}$ \\
\hline Associate professorships & $\begin{array}{l}\text { Tenured position at the EPFL. Includes all other positions in other universities that } \\
\text { are not full professorships, such as extra-ordinary professorships. }\end{array}$ \\
\hline Full professorships & $\begin{array}{l}\text { The highest position in the academic hierarchy in Switzerland, and the highest } \\
\text { possible step of professors' trajectories. }\end{array}$ \\
\hline $\begin{array}{l}\text { Extra-academic } \\
\text { positions }\end{array}$ & $\begin{array}{l}\text { Professional occupations outside academia, such as professional engineer, research } \\
\text { positions in a private company, or research mandates for public organizations. }\end{array}$ \\
\hline Mixed positions & $\begin{array}{l}\text { Career steps that combine academic and extra-academic positions. Divided into: } \\
\text { mixed pre-tenure, mixed associate professorship, and mixed full professorship. }\end{array}$ \\
\hline \multicolumn{2}{|r|}{ 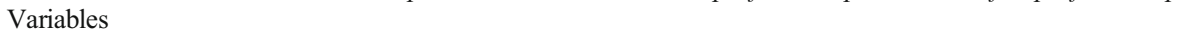 } \\
\hline \multicolumn{2}{|l|}{ Dependent variables } \\
\hline \multirow[t]{4}{*}{ Types of career } & Direct career \\
\hline & Seniority career \\
\hline & Conversion career \\
\hline & Parallel career \\
\hline \multicolumn{2}{|l|}{ Independent variables } \\
\hline \multirow[t]{3}{*}{ Cohorts of nomination } & 1980 cohort (1969-1980) \\
\hline & 2000 cohort $(1981-2000)$ \\
\hline & 2010 cohort $(2001-2010)$ \\
\hline \multirow[t]{5}{*}{ Disciplines } & Basic sciences-SB \\
\hline & Civil Engineering - ENAC \\
\hline & Mechanical Engineering Technical and engineer sciences-STI \\
\hline & Computer sciences-IC \\
\hline & Life sciences-SV \\
\hline \multirow{4}{*}{$\begin{array}{l}\text { Place of assistant } \\
\text { professorship }\end{array}$} & EPFL \\
\hline & Switzerland \\
\hline & Abroad \\
\hline & No position \\
\hline \multirow[t]{4}{*}{ Nationalities } & Swiss \\
\hline & European \\
\hline & American \\
\hline & Other nationalities \\
\hline \multirow[t]{2}{*}{$\mathrm{PhD}$ in the USA } & $\mathrm{PhD}$ obtained in the USA \\
\hline & PhD not obtained in the USA \\
\hline Internal career & Occupied a pre-tenure position at EPFL \\
\hline Spin-off & Involvement in EPFL spin-off \\
\hline Economic mandates & Board membership in any other private company \\
\hline
\end{tabular}

starts with an educational period of 8.9 years on average; the highest degree is obtained at 28.9 years on average. This educational phase is then followed by a relatively short pre-tenure phase ( 7 years on average), which occurs exclusively within academia. At 40 years, $66 \%$ of this cluster is already a full professor; at 50 years, this share is $100 \%$. This indicates a relatively quick access to the academic tenure. This spell was followed by a career leap directly from a post-doctoral position to full professorship often without passing through a period of associate professorship (which, on average, is only 1.6 years).

Seniority $(n=87,25 \%)$ : The seniority career type is characterized by a rather long pretenure phase that follows an educational period of 10.2 years on average. At 40 years, $28 \%$ of this group are associate professors and $67 \%$ are still occupying post-doctoral positions. Following an associate professorship, the appointment as full professor occurs after 45 years of age. Still, at 50, only half of the individuals hold such a position. This last observation clearly distinguishes this type from direct careers. A rather long period in the pre-tenure phase 

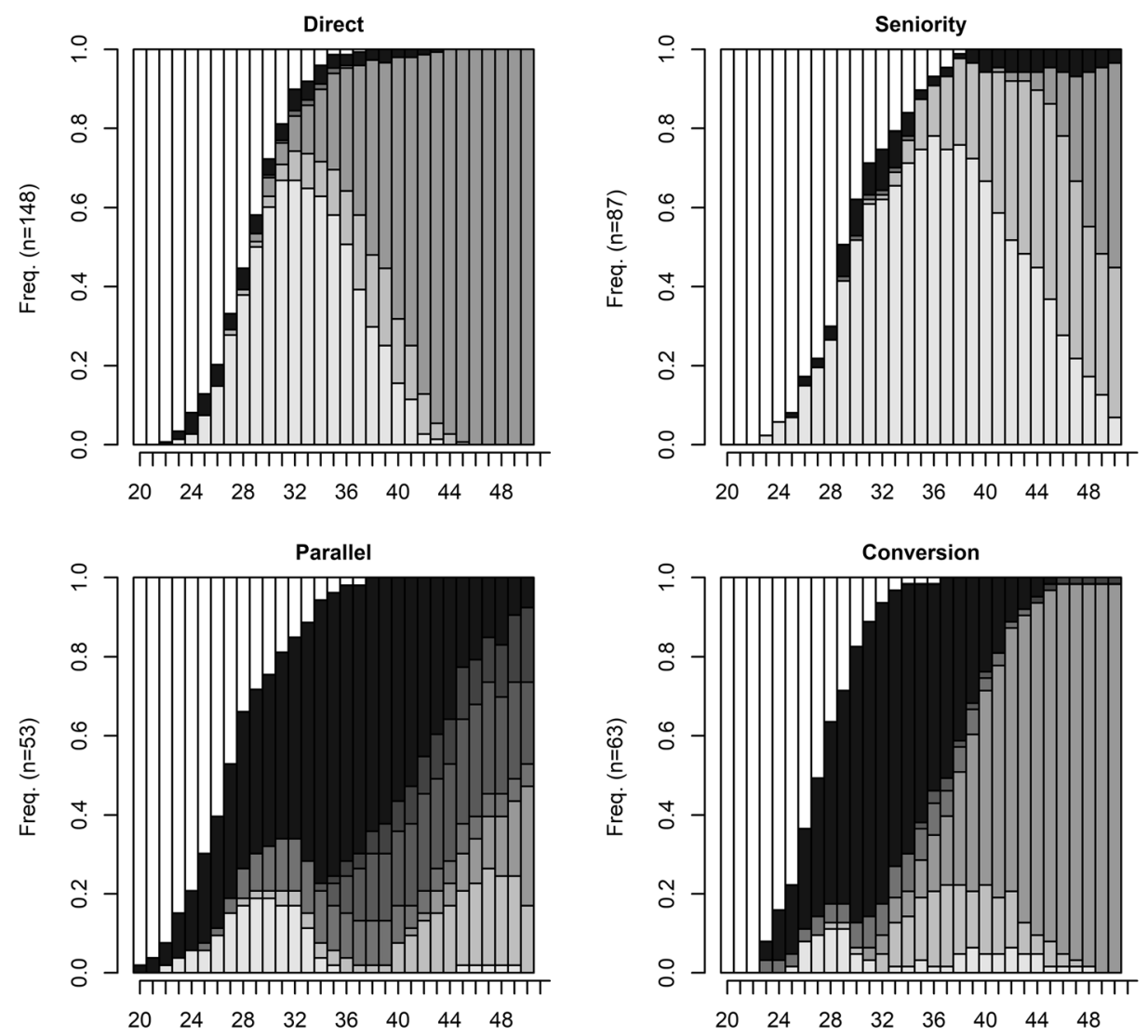

\begin{tabular}{|lll|}
\hline$\square$ Pre-tenure positions & $\square$ Mixed pre-tenure & Extra-academic positions \\
$\square$ Associate professorship & $\square$ Mixed associate professorship & $\square$ Education \\
$\square$ Full professorship & $\square$ Mixed full professorship & \\
\hline
\end{tabular}

Fig. 1 Four career types of professors' careers

almost never leads to a full professorship and, if it does, only after a period of an associate professorship.

Conversion ( $n=63,18 \%)$ : In this cluster, the educational period lasts 7.8 years on average. Following this, however, the members of this type quit academia and work, on average, for 8.6 years in the corporate world. Subsequently, they return to university and are either directly recruited as full professors or pass through a short period of associate professorship (1.9 years) before becoming a full professor. They are not required to earn their way up within the university hierarchy. Rather, they directly convert the practical capital acquired in their corporate career years into a tenured position. At the age of 50, virtually all of those pursuing this type of career have become full professors.

Parallel $(n=53,15 \%)$ : The parallel career type starts with the shortest educational period of all types, in most cases followed by a long spell in the corporate world. At $40,93 \%$ of the clusters are holding either positions in the private sector or "mixed" positions combining a professorship and an activity in the corporate world. This second type including extra-academic states differs from the conversion type in two 
ways: first, the extended period of professional employment in the private sector exhibits a process of accumulated practical capital that is only progressively converted into a professorship. Second, unlike the careers based on conversion, parallel careers lead to lower positions, such as an associate professorship.

\section{Career types according to cohort, discipline, and the place of assistant professorship}

This second descriptive part illustrates how these types vary according to cohort, discipline, and the place of assistant professorship. Cohorts illustrate the organizational re-positioning, disciplines underline the differences between "pure" and "applied" sciences, and the place of assistant professorship distinguishes between local and international endowment with scientific capital.

\section{Development of career types according to the nomination cohort}

We first consider the global evolution of the career types according to the nomination cohorts. Our results reflect the impact of the organizational changes associated with the transformation in an entrepreneurial university on careers: while the accumulation of scientific capital continues to be valued, the likelihood of being able to convert practical capital into a professorship sharply declines in the last cohort (Fig. 2).

For all three cohorts, direct careers are the most important cluster (between 40 and $45 \%$ ). It is noteworthy that the transition to an entrepreneurial university (evidenced by the 2010 cohort) has not led to an upsurge of direct careers. Conversion and parallel careers, which both involve extra-academic career spells, are clearly declining from the oldest to the youngest cohort of nomination. In particular, conversion careers, which still add up to a quarter of all careers in the 1980 cohort, decrease in size to only about $5 \%$ in the 2010 cohort. Also, the importance of parallel careers decreases steadily between 1980 and 2010, albeit at a slower pace: While they amount

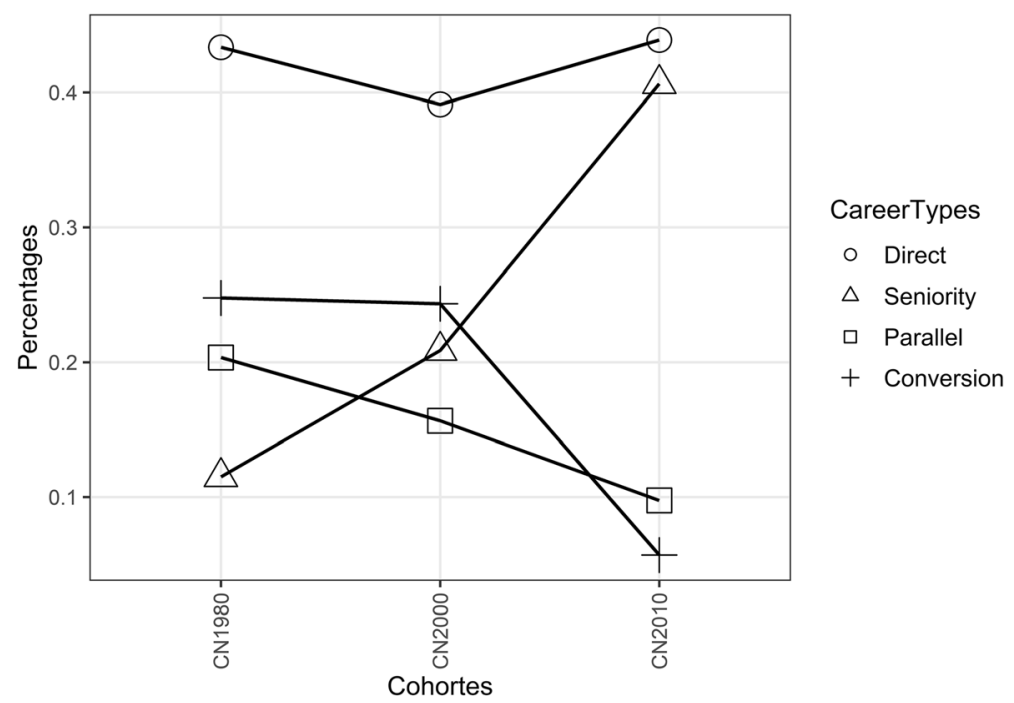

Fig. 2 The share of career types in three nomination cohorts 
to $20 \%$ of all careers in 1980 , they only add up to $10 \%$ in 2010 . More and more of these careers combining practical and scientific capital have been replaced by seniority careers, occurring exclusively within academia. Whereas only $10 \%$ of the 1980 cohort pursued a seniority career, this value rises to $40 \%$ in the 2010 cohort. This finding means that, somewhat counterintuitively, professors' careers are increasingly based on the slow accumulation of scientific capital.

\section{Career types according to discipline}

Second, we consider the distribution of disciplines among career types (Table 3). The professors of basic sciences are overrepresented in the direct careers and underrepresented in the other clusters, especially in conversion careers and parallel careers. The professors of applied disciplines such as civil engineering or mechanical engineering are overrepresented in the practical career types and underrepresented in direct careers.

These descriptive findings seem to confirm what we know about "pure" and "applied" disciplines: While the early display of scientific capital is important for pure science, future professors of applied disciplines are more easily able to convert their experiences in practical domains outside university into positions at the professor level.

\section{Career types and assistant professorships}

Finally, we examine whether professors of the four career types were appointed as assistant professors. This finding reveals whether an assistant professorship rather accelerates careerssuch as in a direct career - or if it leads to a slow-down of the careers (such as in seniority careers). We distinguish between assistant professorships at the EPFL, in Switzerland, and abroad.

About $75 \%$ of all professors have never held a position as assistant professor. Examining the $25 \%$ who have, it appears that it is not (only) the position as assistant professor as such that matters. What shapes careers is the place of assistant professorships (Table 4): Whereas those who have been an assistant professor abroad are overrepresented in the direct cluster, those who were in the same position in Switzerland - and to a greater extent, those who were at the EPFL - are overrepresented in the seniority career.

\section{Explaining career types}

To consolidate these descriptive analyses, we run four binomial logistic regressions (Table 5). Each model takes the affiliation with a specific cluster as a dependent variable.

Table 3 Share of disciplines in the four career types (in \%)

\begin{tabular}{llllll}
\hline & \multicolumn{2}{l}{ Clusters } & & & Sample \\
\cline { 2 - 5 } Departments & Direct & Seniority & Conversion & Parallel & Mean \\
\hline \% Basic Sciences & 43.2 & 26.4 & 19.0 & 5.7 & 29.1 \\
\% Civil Engineering & 17.6 & 33.3 & 23.8 & 50.9 & 27.6 \\
\% Mechanical Engineering & 20.9 & 20.7 & 36.5 & 37.7 & 26.2 \\
\% Computer Science & 8.8 & 3.4 & 14.3 & 1.9 & 7.4 \\
\% Life Science & 6.8 & 11.5 & 3.2 & 3.8 & 6.8 \\
\% Technology Management & 2.7 & 4.6 & 3.2 & 0.0 & 2.8 \\
\hline
\end{tabular}


Table 4 Share of the place of assistant professorship in the four career types (in \%)

\begin{tabular}{llllll}
\hline & \multicolumn{2}{l}{ Clusters } & & & Sample \\
\cline { 2 - 5 } Place of assistant professorship & Direct & Seniority & Conversion & Parallel & Mean \\
\hline \% EPFL & 6.1 & 13.8 & 3.2 & 5.7 & 7.4 \\
$\%$ Swiss & 5.4 & 5.7 & 0.0 & 5.7 & 4.6 \\
$\%$ Abroad & 23.0 & 10.3 & 1.6 & 1.9 & 12.8 \\
$\%$ No position & 65.5 & 70.1 & 95.2 & 86.8 & 75.2 \\
\hline
\end{tabular}

The nomination cohorts are important factors for explaining the membership in the seniority and the conversion career, but not for the two others. Compared with the 1980 cohort, we see that the 2000 and 2010 cohorts are positively associated with the seniority type of careers. The chances of professors nominated between 1980 and 2000 to pursue a seniority career are 15\% higher than for those nominated between 1969 and 1980. The effect for the

Table 5 Logistic regression models on the four career types

\begin{tabular}{|c|c|c|c|c|c|c|c|c|c|c|c|c|}
\hline & \multicolumn{3}{|l|}{ Direct } & \multicolumn{3}{|c|}{ Seniority } & \multicolumn{3}{|c|}{ Conversion } & \multicolumn{3}{|c|}{ Parallel } \\
\hline & Coef & AME & Sig. & Coef & AME & Sig. & Coef & AME & Sig. & Coef & AME & Sig. \\
\hline (Intercept) & 0.48 & & & -2.70 & & $* * *$ & -0.87 & & $*$ & -3.30 & & $* * *$ \\
\hline 2000 cohort & -0.34 & -0.07 & & 0.94 & 0.15 & $*$ & -0.32 & -0.04 & & -0.18 & -0.02 & \\
\hline 2010 cohort & -0.63 & -0.13 & & 2.01 & 0.35 & $* * *$ & -1.78 & -0.18 & $* *$ & -0.11 & -0.01 & \\
\hline $\begin{array}{c}\text { Nationalities: } \\
\text { European }\end{array}$ & -0.06 & -0.01 & & 0.15 & 0.02 & & 0.10 & 0.01 & & -0.38 & -0.04 & \\
\hline $\begin{array}{c}\text { Nationalities: } \\
\text { American }\end{array}$ & -0.27 & -0.05 & & 0.31 & 0.05 & & 0.79 & 0.11 & & -0.18 & -0.02 & \\
\hline Nationalities: Other & -0.04 & -0.01 & & 0.43 & 0.07 & & -0.96 & -0.10 & & 0.49 & 0.06 & \\
\hline $\begin{array}{l}\text { Discipline: Civil } \\
\text { Engineering }\end{array}$ & -1.54 & -0.30 & $* * *$ & 0.79 & 0.13 & $*$ & -0.09 & -0.01 & & 2.51 & 0.32 & $* * *$ \\
\hline $\begin{array}{l}\text { Discipline: } \\
\text { Mechanical } \\
\text { Engineering }\end{array}$ & -1.14 & -0.22 & $* * *$ & 0.12 & 0.02 & & 0.43 & 0.05 & & 2.28 & 0.28 & $* * *$ \\
\hline $\begin{array}{l}\text { Discipline: } \\
\text { Computer } \\
\text { Science }\end{array}$ & -0.32 & -0.06 & & -0.99 & -0.13 & & 1.55 & 0.23 & $*$ & 0.42 & 0.05 & \\
\hline $\begin{array}{l}\text { Discipline: Life } \\
\text { Sciences }\end{array}$ & -0.44 & -0.09 & & 0.31 & 0.05 & & 0.26 & 0.03 & & 1.10 & 0.15 & \\
\hline $\mathrm{PhD}$ in the USA & 0.41 & 0.09 & & -0.42 & -0.06 & & 0.41 & 0.05 & & -0.54 & -0.05 & \\
\hline $\begin{array}{l}\text { Place of assistant } \\
\text { professorship: } \\
\text { EPFL }\end{array}$ & -0.02 & 0.00 & & -0.54 & -0.08 & & 0.97 & 0.13 & & -0.03 & 0.00 & \\
\hline $\begin{array}{l}\text { Place of assistant } \\
\text { professorship: } \\
\mathrm{CH}\end{array}$ & 0.67 & 0.14 & & 0.33 & 0.05 & & -16.25 & -0.19 & & 0.12 & 0.01 & \\
\hline $\begin{array}{l}\text { Place of assistant } \\
\text { professorship: } \\
\text { abroad }\end{array}$ & 1.63 & 0.35 & $* * *$ & -0.38 & -0.06 & & -2.71 & -0.18 & $*$ & -1.83 & -0.13 & . \\
\hline Internal career: Yes & 0.07 & 0.02 & & 1.16 & 0.20 & $* *$ & -1.87 & -0.18 & $* *$ & -0.20 & -0.02 & \\
\hline Spin-off: yes & -0.02 & -0.01 & & 0.04 & 0.01 & & 0.18 & 0.02 & & -0.16 & -0.02 & \\
\hline $\begin{array}{l}\text { Economic } \\
\text { mandates: Yes }\end{array}$ & 0.04 & 0.01 & & -0.47 & -0.07 & & 0.16 & 0.02 & & 0.41 & 0.05 & \\
\hline
\end{tabular}

$* * * \mathrm{p}<0.001, * * \mathrm{p}<0.01, * \mathrm{p}<0.05$ 
2010 cohort is stronger (35\%), meaning that professors nominated under the entrepreneurial university regime are more likely to pursue a rather long period of scientific capital accumulation before the tenure, respectively before getting full professorship. Regarding the conversion career, the 2010 cohort has a strong negative effect with an average marginal effect of 0.18 . The recent organizational reforms seem to lead not only to an increase in the seniority careers but also to a decline in the careers based on the conversion of practical capital, making it less valuable than scientific capital.

The results show more of a disciplinary logic of distinction for the two other career types. Taking basic sciences as reference category, professors of civil and mechanical engineering are significantly underrepresented in direct careers and overrepresented in parallel careers. The average marginal effect of inclusion in the direct cluster is negative for professors of the civil engineering department $(-0.30)$ or the mechanical engineering department $(-0.22)$ when comparing with SB. In contrast, being in the civil or mechanical engineering department strongly increases the chance of inclusion in the parallel cluster (32\% for civil and $28 \%$ for mechanical engineering). These results illustrate that scientific capital is related to basic sciences and direct careers, while practical capital is related to applied sciences and parallel careers. The types "seniority" and "conversion" are hardly correlated with disciplinary logic, but more to institutional transformations measured by the cohorts of nomination.

The regression shows that the assistant professorship abroad has a strong effect on direct careers (35\%) and, inversely, has a negative effect on the conversion type (-0.18). We see that the assistant professorship at the EPFL does not significantly distinguish between career types. However, and not surprisingly, having had an internal career before the tenure professorship increases the chances of belonging to seniority careers by $20 \%$. The introduction of the tenure track model in 2001 has, contrary to its initial purpose, no accelerating effect on professors' careers. On the contrary, the internal career contributes, to a large extent, to the seniority type. ${ }^{8}$ In this case, an internal assistant professorship rather prolongs the pre-tenure phase and does not work as a career accelerator.

\section{Discussion}

Two types of academic careers dominate the professoriate at the EPFL in the most recent cohort: direct and seniority careers. While the first has always been an integral part of the basic science disciplines (see Table 3), the rise of the second is conspicuous and seems to illustrate a new archetype for slower and incremental academic careers. The institutional formalization and standardization of academic careers described as a trend in Western university systems by Musselin (2005) have led to careers characterized by slower accumulation of scientific capital over time. While a fair share of careers is still based on the early identification of excellence, the trend goes toward more cumulative careers. Only after a long phase of observation and tests does an institution such as the EPFL promote its professors to the status of full professorship.

What is more, we find that the mix between scientific capital and practical capital still very much depends on the discipline. While practical capital accumulated in the corporate world enjoys a high value in applied sciences and can be converted into university positions, this is not the case for basic sciences. Furthermore, our analyses show that this practical capital has

\footnotetext{
${ }^{8}$ It is not excluded that the rise of "seniority careers" is also due to more "reluctant" promotions of "older" staff in in-house career.
} 
been devaluated with the implementation of the entrepreneurial university, even for the applied sciences. In other words, the strengthening of the academic heartland (Clark 1998) means that trajectories in the applied sciences have become more academic, while those in the pure disciplines basically function as before. Professors of pure scientific disciplines are also hardly represented among the founders of start-ups or spin-offs and do barely have any other business mandates. More generally, none of the trajectories are specifically linked to board positions in start-ups/spin-offs or other corporate companies. For the EPFL, at least, we cannot confirm the assumption of the literature on the growing role of such new links to the corporate world.

Strategically, the EPFL uses assistant professorships in two different ways: external assistant professorships, in particular at prestigious American universities, work as a signal for excellence. Candidates endowed with such international capital are recruited and directly promoted to full professorships at the EPFL at a relatively early stage of their career, comparable to the traditional direct careers. Internal assistant professors are much more cautiously tested. They undergo a rather lengthy procedure of internal evaluation, and are promoted later and often only to associate professorships rather than directly to full professorships. In terms of resources, this means that scientific capital has taken on an international flavor, and a combination of scientific and international capital is the new sign for excellence. What is important for professors' careers is not the status of assistant professorships as such but their differential symbolic loading with international capital. ${ }^{9}$

\section{Conclusion}

The aim of this article was to study professors' careers and their recent transformation in a context in which the entrepreneurial university appears as a new model for technical universities. Three research questions structured our argument: Have professors' careers become more standardized and slower across cohorts? What about the career differences in pure and applied disciplines? And how has the introduction of assistant professorships transformed careers in recent years? We studied these questions based on a full sample $(N=351)$ of three nomination cohorts of professors at the EPFL. Thanks to a sequence analysis, we have identified four career types: direct, seniority, conversion, and parallel. Using this typology as a dependent variable in four binomial regression models, we then showed that (1) seniority careers have become more important in recent cohorts, while practical careers (conversion, parallel) have become less important. We still observe (2) differences between applied and pure disciplines: while in disciplines of basic sciences direct careers are overrepresented, applied disciplines still have relatively large shares of professors pursuing practical careers. An examination of (3) the meaning of assistant professorships for professors' careers shows that this position does not guarantee a direct access to full professorship. While professors who were assistant professors abroad pursue direct careers, the internal assistant professors often are on a trajectory that resembles the seniority career type.

These results make the following contributions to the larger literature on professors' careers and the academic profession: the lion's share of the literature on academic careers concentrates on national contexts, institutional governance models, and formal rules that regulate these

\footnotetext{
${ }^{9}$ It is possible also that this is a strategy to strengthen the attractiveness of professorial positions at EPFL to recruit promising young scholars from abroad on tenure track assistant professor positions, before they actually obtain a tenured position in their home country.
} 
trajectories. To assess whether the implementation of the entrepreneurial university has led to changes in academic trajectories, our analysis focuses on actual career sequences of professors. Sequence analysis allowed us to follow the individual trajectories and to focus on durations and transitions between career spells to measure the process of accumulation and conversion of scientific and practical capitals. While it has so far only rarely been used to investigate academic careers, this method has proven to be heuristic to understand how actual careers of professors at the EPFL react to institutional changes.

A second contribution of our article owes its salience to the rather internationalized character of Swiss academia and EPFL in particular. As the literature on academic careers is focused on the institutional landscape, it typically distinguishes between national models. Musselin (2005), for instance, compares the "models" of the USA, France, and Germany; Kreckel and Zimmermann (2014) descriptively list a large number of different national models of academic careers. Even though such a national silo perspective might make sense in an institutionalist perspective, it struggles to grasp both specific organizational reorientations and the increasing international mobility of academic careers. The case of the EPFL shows that academic careers can be shaped by both particular organizational changes and the interaction of different national systems. Therefore, more research is needed on the articulation between different academic career systems and changing universities' governance, and how this interaction produces scientific prestige.

Funding information Open access funding provided by University of Applied Sciences and Arts Western Switzerland (HES-SO). This research was funded by the project "Academic Elites in Switzerland 1910-2000: between Autonomy and Power" (Swiss National Science Foundation, N¹43202).

Open Access This article is licensed under a Creative Commons Attribution 4.0 International License, which permits use, sharing, adaptation, distribution and reproduction in any medium or format, as long as you give appropriate credit to the original author(s) and the source, provide a link to the Creative Commons licence, and indicate if changes were made. The images or other third party material in this article are included in the article's Creative Commons licence, unless indicated otherwise in a credit line to the material. If material is not included in the article's Creative Commons licence and your intended use is not permitted by statutory regulation or exceeds the permitted use, you will need to obtain permission directly from the copyright holder. To view a copy of this licence, visit http://creativecommons.org/licenses/by/4.0/.

\section{References}

Abbott, A., \& Hrycak, A. (1990). Measuring resemblance in sequence data: an optimal matching analysis of musicians' careers. American Journal of Sociology, 96(1), 144-185.

Aebischer, P., \& Ricci, J. F. (2006). The organizational challenge for European universities facing globalization. In L. Weber \& J. Duderstadt (Eds.), Universities and business: partnering for the knowledge society (pp. 183-193). London: Economica.

Becker, H. S. (1963). Outsiders. Studies in the sociology of deviance. New York: Free Press of Glencoe.

Benninghoff, M., \& Braun, D. (2010). Research funding, authority relations, and scientific production in Switzerland. In R. Whitley, J. Gläser, \& L. Engwall (Eds.), Reconfiguring knowledge production (pp. 81109). Oxford: Oxford university Press.

Blanchard, P., Bühlmann, F., \& Gauthier, J.-A. (2014). Advances in sequence analysis: theory, methods, applications. New York: Springer.

Bourdieu, P. (1976). Le champ scientifique. Actes de la Recherche en Sciences Sociales, 2(2), 88-104.

Bourdieu, P. (1984). Distinction. London: Routledge \& Kegan Paul.

Bourdieu, P. (1990). Homo Academicus. Cambridge: Polity Press. 
Braun, D. (2001). Regierungsmodelle und Machtstrukturen an Universitäten. In E. Stölting \& U. Schimank (Eds.), Die Krise der Universitäten (pp. 243-263). Wiesbaden: Westdeutscher Verlag.

Bühlmann, F. (2008). The corrosion of career? Occupational trajectories of business economists and engineers in Switzerland. European Sociological Review, 24(5), 601-616.

Bühlmann, F., David, T., \& Mach, A. (2013). Cosmopolitan capital and the internationalization of the field of business elites: evidence from the Swiss case. Cultural Sociology, 7(2), 211-229.

Clark, B. R. (1998). Creating entrepreneurial universities: organizational pathways of transformation. Oxford: Pergamon Press.

Cosandey, M. (1999). Histoire de l'Ecole Polytechnique Lausanne: 1953-1978. Lausanne: PPUR.

Dlouhy, K., \& Biemann, T. (2015). Optimal matching analysis in career research: a review and some bestpractice recommendations. Journal of Vocational Behaviour, 90, 163-173.

Enders, J. (2001). A chair system in transition: appointments, promotions, and gate-keeping in German higher education. Higher Education, 41(1-2), 3-25.

Enders, J., \& De Weert, E. (2004). Science, training and career: changing modes of knowledge production and labour markets. Higher Education Policy, 17(2), 135-152.

Etzkowitz, H., \& Viale, R. (2010). Polyvalent knowledge and the entrepreneurial university: a third academic revolution? Critical Sociology, 36(4), 595-609.

Feibleman, J. K. (1961). Pure science, applied science, technology, engineering: an attempt at definitions. Technology and Culture, 2(4), 305-317.

Foss, L., \& Gibson, D. V. (2015). The entrepreneurial university: context and institutional change. London: Routledge.

Fumasoli, T., \& Goastellec, G. (2015). Global models, disciplinary and local patterns in academic recruitment processes. In T. Fumasoli, G. Goastellec, \& B. M. Kehm (Eds.), Academic work and careers in Europe: trends, challenges, perspectives (pp. 69-93). New York: Springer.

Gabadinho, A., Ritschard, G., \& Studer, M. (2011). Analyzing and visualizing state sequences in R with TraMineR. Journal of Statistical Software, 40(4), 1-37.

Gibbons, M., Limoges, C., Nowotny, H., Schwartzman, S., Scott, P., \& Trow, M. (1994). The new production of knowledge: the dynamics of science and research in contemporary societies. London: Sage.

Goastellec, G. \& Benninghoff, M. (2011). Formaliser les règles, harmoniser les procédures et accroitre la compétitivité. Une professionnalisation des carrières académiques helvétiques?. Cahiers de la recherche sur l'éducation et les savoirs, (Hors-série n 3), 129-147.

Goastellec, G., \& Pekari, N. (2013). The internationalisation of academic markets, careers and professions. In U. Teichler \& E. A. Höhle (Eds.), The work situation of the academic profession in Europe: findings of a survey in twelve countries (pp. 229-248). Dordrecht: Springer.

Hughes, E. C. (1937). Institutional office and the person. American Journal of Sociology, 43(3), 404-413.

Kaulisch, M., \& Enders, J. (2005). Careers in overlapping institutional contexts: the case of academe. Career Development International, 10(2), 130-144.

Kreckel, R., \& Zimmermann, K. (2014). Hasard oder Laufbahn. Akademische Karrierestrukturen im internationalen Vergleich. Leipzig: Akademische Verlagsanstalt.

Lepori, B. (2007). La politique de la recherche en Suisse. Institutions, acteurs et dynamique historique. Bern: Haupt Verlag.

Leresche, J. P., Joye-Cagnard, F., Benninghoff, M., \& Ramuz, R. (2012). Gouverner les universités: l'exemple de la coordination Genève-Lausanne, 1990-2010. Lausanne: PPUR.

Long, J. S. (1997). Regression models for categorical and limited dependent variables. Advanced quantitative techniques in the social sciences (Vol. 7). Thousand Oaks: Sage.

Musselin, C. (2005). European academic labor markets in transition. Higher Education, 49(1), 135-154.

Musselin, C. (2013). Redefinition of the relationships between academics and their university. Higher Education, 65(1), 25-37.

Paradeise, C., \& Crow, M. (2009). Une «nouvelle université américaine»? Arizona State University. Le Débat, $156,117-127$.

Pont, M. (2010). Chronique de l'EPFL 1978-2000. L'âge d'or de l'ingénierie. Lausanne: PPUR.

Rossier, T. (2020). Accumulation and conversion of capitals in professorial careers. The importance of scientific reputation, network relations, and internationality in economics and business studies. Higher Education, 1-20.

Sam, C., \& Van Der Sijde, P. (2014). Understanding the concept of the entrepreneurial university from the perspective of higher education models. Higher Education, 68(6), 891-908. 
Savage, M., Warde, A., \& Devine, F. (2005). Capitals, assets, and resources: some critical issues. The British Journal of Sociology, 56(1), 31-47.

Schuster, J. H., \& Finkelstein, M. J. (2006). The American faculty: the restructuring of academic work and careers. Baltimore: Johns Hopkins University Press.

Stephan, P., \& Ma, J. (2005). The increased frequency and duration of the postdoctorate career stage. American Economic Review, 95(2), 71-75.

Vaara, E., \& Faÿ, E. (2012). Reproduction and change on the global scale: a Bourdieusian perspective on management education. Journal of Management Studies, 49(6), 1023-1051.

Publisher's note Springer Nature remains neutral with regard to jurisdictional claims in published maps and institutional affiliations.

\section{Affiliations}

\section{Pierre Benz ${ }^{1,2} \cdot$ Felix Bühlmann ${ }^{3} \cdot$ André Mach $^{4}$}

1 Institute of Social Sciences (ISS), University of Lausanne, GEO-5346, CH-1015 Lausanne, Switzerland

2 Faculty of Social Work (HETSL|HES-SO), University of Applied Sciences and Arts Western Switzerland, Lausanne, Switzerland

3 Institute of Social Sciences (ISS), University of Lausanne, GEO-5142, CH-1015 Lausanne, Switzerland

4 Institute of Political Studies (IEP), University of Lausanne, GEO-4783, CH-1015 Lausanne, Switzerland 